\title{
Motivation of Non-Muslims to Become Customers at PT. Bank Syariah Mandiri KC. Sibolga
}

\author{
Amsal $^{1}$, Fatahuddin ${ }^{2}$, Idris $^{3}$, Ferri $^{4}$ \\ ${ }^{1}$ IAIN Padangsidimpuan (Hukum Syariah, FEBI, IAIN Padangsidimpuan) \\ ${ }^{2}$ IAIN Padangsidimpuan (Perbankan Syariah, FEBI, IAIN Padangsidimpuan) \\ ${ }^{3}$ IAIN Padangsidimpuan (Perbankan Syariah, FEBI, IAIN Padangsidimpuan) \\ ${ }^{4}$ IAIN Padangsidimpuan (Perbankan Syariah, FEBI, IAIN Padangsidimpuan) \\ amsal@gmail.com ${ }^{1}$, fatahuddin@iain-padangsidimpuan.ac.id ${ }^{2}$, idrissaleh@iain-padangsidimpuan.ac.id ${ }^{3}$ \\ ferri@iain-padangsidimpuan.ac.id ${ }^{4}$
}

\begin{abstract}
ABSTRAK
Latar belakang masalah dalam penelitian ini adalah PT. Bank Syariah Mandiri KC. Sibolga tidak hanya memiliki nasabah yang beragama Islam akan tetapi PT Bank Syariah Mandiri KC. Sibolga memiliki nasabah non muslim yang mencapai hampir setengah dari total keseluruhan nasabah yang termotivasi untuk melakukan transaksi di bank tersebut. Hal itu menunjukan bahwa PT Bank Syariah Mandiri KC. Sibolga dapat diterima dengan baik oleh masyarakat non muslim di kota Sibolga. Pembahasan penelitian ini berkaitan dengan bidang ilmu perbankan syariah. Bank syariah adalah lembaga keuangan yang mendorong dan mengajak masyarakat untuk ikut berinvestasi dalam berbagai produk berdasarkan prinsip syariah. Sedangkan Motivasi adalah suatu set atau kumpulan perilaku yang memberikan landasan bagi seseorang untuk bertindak dalam suatu cara yang diarahkan kepada tujuan spesifik tertentu. Metode penelitian yang dilakukan adalah penelitian kualitatif dengan menggunakan pendekatan deskriptif. Jenis data yang digunakan adalah sumber data primer dan sumber data skunder. Taknik pengumpulan data dengan observasi, wawancara dan dokumentas. Berdasarkan hasil penelitian yang dilakukan, peneliti melihat pada umumnya banyak masyarakat non muslim termotivasi dengan pelayanan yang dilakukan oleh PT. Bank Syariah Mandiri KC. Sibolga. motivasi masyarakat non muslim menjadi nasabah di PT. Bank Syariah Mandiri KC. Sibolga lokasinya sangat terjangkau, promosi yang dilakukan oleh PT. Bank Syariah Mandiri KC. Sibolga sangat giat dengan cara bersosialisasi di pasar maupun di Sekolah. Selain itu ada juga yang mengatakan karena aturan kantor KEMENAG yang merekomendasikan supaya menjadi nasabah di PT. Bank Syariah Mandiri KC. Sibolga.
\end{abstract}

Kata Kunci: Bank Syariah, Motivasi, Non Muslim

\begin{abstract}
The background of the problem in this study is PT. Bank Syariah Mandiri KC. Sibolga does not only have customers who are Muslim but PT Bank Syariah Mandiri KC. Sibolga has non-Muslim customers who account for almost half of the total customers who are motivated to make transactions at the bank. This shows that PT Bank Syariah Mandiri KC. Sibolga is well received by the non-Muslim community in the city of Sibolga. Discussion of research related to the field of Islamic banking. Islamic banks are financial institutions that encourage and invite the public to participate in various products based on sharia principles. While motivation is a set or collection of behaviors that provide a basis for a person to act in a way that is directed towards certain specific goals. The research method used is qualitative
\end{abstract}


research using a descriptive approach. The types of data used are primary data sources and secondary data sources. Taknik followed the data with observation, interviews and documentation. Based on the results of the research conducted, researchers saw that in general the non-Muslim community was motivated by the services provided by PT. Bank Syariah Mandiri KC. Sibolga. motivation of the non-Muslim community to become customers at PT. Bank Syariah Mandiri KC. Sibolga's location is very affordable, a promotion conducted by PT. Bank Syariah Mandiri KC. Sibolga is very suitable with socializing in the market and at school. In addition there are also those who change because of the rules of the Ministry of Religion office that roam as customers at PT. Bank Syariah Mandiri KC. Sibolga.

Keywords: Bank Syariah, motivation, non-Muslim

\section{A. PENDAHULUAN}

Perbankan syariah sebagai alternatif dari sistem perbankan konvensional maka harus memiliki peraturan khusus, dimana perbankan syariah harus lebih universal. Dimana peraturan tersebut bukan hanya untuk kalangan umat muslim, tetapi untuk kalangan non muslim juga. Baik itu dalam bentuk produk, layanan ataupun sistem di dalam lembaga perbankan syariah tersebut, sehingga dapat mempengaruhi para nasabah untuk dijadikan alasan-alasan atau pengaruh dalam menetapkan hatinya kepada bank syariah, maka bagi lembaga perbankan syariahnya sendiri pun tidak akan menutup kemungkinan untuk nasabah non muslim.(Syarofah: 2016, 1)

Banyak yang beranggapan bank syariah itu hanya diperuntuhkan untuk orang-orang muslim, karena bank syariah dalam menjalankan kegiatan usahanya berdasarkan pada prinsip Islam, maka sebagian orang akan berpandangan bahwa bank syariah ini identik dengan Islam dan umat Islam. Dengan kata lain, bank syariah hanya diperuntuhkan kepada orang-orang yang beragama Islam saja, sedangkan agama lain (non muslim) tidak bisa bertransaksi didalamnya. Pandangan ini tentu keliru dan perlu diluruskan. Kalau dikatakan bank syariah itu identik dengan Islam, hal itu memang benar adanya, karena ketika kita berbicara tentang syariah,maka secara otomatis akan bicara tentang Islam. Keduanya merupakan satu kesatuan yang tidak bisa dipisahkan. Namun yang perlu dipahami, bank syariah tidak terkait sama sekali dengan ritual keagamaan atau peribadatan dari agama Islam. Karena Islam ialah suatu pandangan yang mengatur semua sisi kehidupan manusia atau cara hidup, maka tidak ada satupun aspek kehidupan manusia yang terlepas dari ajaran Islam. Bukankah nabi sendiri menyatakan bahwa "antum a'lamu bi umuri al-dunyakum" (kalian lebih mengetahui urusan dunia kalian). Alquran dan sunnah hanya memberikan prinsipprinsip dan pilosofi dasar, dan menegaskan larangan-larangan yang harus dijahui, dengan demikian yang harus dilakuhkan hanyalah 
mengidentifikasi hal-hal yang dilarang oleh Islam.(Karim: 2016, 15)

Kini, perbankan syariah telah mengalami perkembangan yang cukup pesat dan menyebar ke banyak negara, bahkan ke negara-negara barat, The Islamic Bank International of Denmark tercatat sebagai bank syariah pertama yang beroperasi di Eropa. Kini, bank-bank besar di negara barat, seperti Citibank, ANZ Bank, Chase Manhattan Bank, dan Jurnide Fleming telah membuka Islamic Window agar dapat memberikan jasa-jasa perbankan yang sesuai dengan syariat Islam.(Machmud: 2010, 19)

Bank syariah dalam menjalankan kegiatannya, tidak terbatas hanya untuk orang yang beragama Islam saja, tapi juga terbuka bagi non muslim, dengan kata lain bank syariah bisa memberikan pembiayaan atau jasa kepada non muslim. Kaum non muslim bisa menabung, meminta pembiayaan dan menggunakan jasa bank syariah. Perbankan syariah saat ini sudah tumbuh atau berkembang dengan pesat diseluruh dunia, bahkan sudah tidak asing lagi jika bank-bank syariah mempunyai masyarakat non muslim, baik di dalam negeri maupun di luar negeri. Karena kini perbankan syariah telah mengalami perkembangan yang cukup pesat dan menyebar ke banyak negara-negara barat. Sedangkan di Indonesia ini juga sudah terdapat bank syariah mandiri yang sudah memiliki nasabah non muslim seperti halnya di PT. Bank Syariah Mandiri KC. Sibolga Kota Sibolga 31 \% nasabah non muslim, dari seluruh nasabah yang jumlahnya 16.000 , dan total nasabah non muslim berjumlah 5.000. Hal ini mengidentifikasikan secara jelas bahwa Bank Syariah tidak hanya untuk orang yang beragama Islam saja.(Nilma: 19 Oktober 2020)

Ada hal yang perlu diperhatikan oleh PT. Bank Syariah Mandiri KC. Sibolga yang mana harus dilaksanakan demi eksistensinya sebuah bank terutama pada reputasi bank dan demi mendapatkan loyalitas dari nasabahnya. Yang pertama tidak membedakan nasabah dari segi sosial, selain itu juga para pegawai tidak membedakan dari segi agama, baik Islam maupun non muslim layanan yang diberikan juga harus sama dan tidak membandingkan satu sama lain. Kedua, tata krama yang sopan dan ramah akan membuat nasabah merasa nyaman terhadap Bank Syariah Mandiri KC. Sibolga.

Oleh karena itu Menurut Buchari Alma "Kualitas pelayanan akan mendorong terwujudnya kepuasan pelanggan dan kepuasan pelanggan merupakan salah satu faktor penentu loyalitas, bila kepuasan pelanggan terbentuk maka pertumbuhan perusahaan akan terjamin". Selanjutnya Abdurrahman mengatakan bahwa untuk memenangkan persaingan, perusahaan harus mampu memberikan nilai dan kepuasan kepada pelanggan melalui penyampaian produk dan jasa berkualitas dan harga bersaing. Semua organisasi mempunyai strategi-strategi yang ditempuh untuk masa depan, semua strategi tersebut diharapkan membawa kemajuan yang berarti pada organisasi atau perusahaan, 
kemajuan yang berarti itu tergambar dari keberhasilan pasar. Keberhasilan pemasaran terjadi karena mutu yang baik, respon konsumen terhadap produk juga baik. Tentunya dengan prinsip mutu tersebut, keterlibatan karyawan menjadi hal yang mutlak dan penting dan pada akhirnya tujuan.(Isa: 2019, )

Maka dengan adanya nasabah non muslim ini suatu penghargaan atau kabar baik bagi Perbankan Syariah. Karena pada saat sekarang ini banyak sekali yang kita lihat berdiri di seluruh perkotaan lembaga keuangan konvensional yang menawarkan berbagai macam jenis-jenis produk. Peneliti ini lebih memfokuskan bagaimana motivasi masyarakat non muslim menjadi nasabah di PT. bank syariah mandiri KC. Sibolga. Dimana impian para nasabah sesuai dengan kinerja yang diberiakan oleh bank syariah mandiri kota Sibolga khususnya pada nasabah non muslim.

Masyarakat non muslim tidak mebutuhkan persyaratan yang rumit dan waktu yang lama. Secara umum faktor penyebab rendahnya motivasi masyarakat non muslim menjadi nasabah di PT. Bank Syariah Mandiri KC. Sibolga di duga salah satunya karena faktor minimnya pengetahuan masyarakat non muslim atas produk yang ditawarkan serta minimnya promosi yang dilakukan pihak manajemen bank dalam memperkenalkan produk-produng yang ada di PT. Bank Syariah Mandiri KC. Sibolga.

Sebagaimana hal serupa yang yang di ungkapkan Ibu Cristiana Berliana mengatakan, bahwa beliau termotivasi menjadi nasabah di
POINT Vol. 1, No. 2, Des 2020 PT. Bank Syariah Mandiri KC. Sibolga melalui informasi dari temannya yang juga nasabah non muslim di PT. Bank Syariah Mandiri KC. Sibolga. karena beliau membutuhkan dana secara cepat dan tidak membutuhkan waktu yang lama serta pelayanan yang diberikan oleh pihak bank sangat ramah-ramah. Begitu juga dengan lokasinya sangat strategis mudah di jangkau.(Berliana; 23 November 2020.) Setiap masyarakat memiliki motivasi yang berbedabeda terkait keputusan menjadi nasabah non muslim di PT. Bank Syariah Mandiri KC. Sibolga.

\section{B. METODE}

Dalam penelitian ini menggunakan penelitian kualitatif, dengan metode deskriptif. Metode deskriptif adalah merupakan metode penelitian yang berusaha menggambarkan, menginterpretasikan objek sesuai dengan apa adanya dan berusaha menggambarkan secara sistimatis fakta, data dan karakteristik objek atau subjek yang diteliti secara tepat.

Mardalis menyebutkan bahwa penelitian kualitatif yang bersifat deskriptif bertujuan untuk mendeskripsikan apa-apa yang saat ini terjadi dan berlaku, yang didalamnya terdapat upaya mendeskripsikan, mencatat menganalisis dan menginterpretasikan kondisi-kondisi yang terjadi atau ada.(Mardalis: 2007, 26)

Unit analisis / subjek penelitian ini memperoleh data langsung dari masyarakat non muslim yang menjadi nasabah di PT. Bank Syariah Mandiri KC. Sibolga sebanyak 30 orang sebagai informan yang langsung diwawancarai. 
Selanjutnya jika dalam proses pengumpulsn data sudah tidak lagi ditemukan variasi informasi, maka peneliti tidak perlu lagi untuk mencari informan baru, proses pengumpulan informasi dianggap selesai. Dengan demikian, penelitian kualitatif tidak dipersoalkan dengan jumlah sampel. Dalam hal ini jumlah sampel atau informasi bisa sedikit, tetapi bisa juga banyak.

Semua penelitian memiliki unit analisis. Yang dimaksud dengan unit analisi penelitian yaitu organisasi, kelompok orang, kejadian, atau hal-hal lain yang dijadikan objek penelitian. Sedangkan Subjek Penelitian adalah yang ditujukan untk diteliti oleh peneliti. Berbecara tentang subjek penelitian berarti berbicara tentang unit analisis. Unit analisis yaitu subjek yang menjadi pusat perhatian atau sasaran penelitian.(Arikunto: 2006, 145)

Adapun yang menjadi sumber data dalam penelitian ini adalah Sumber data primer, data yang didapat peneliti secara langsung (dari tangan pertama).(Subagyo: 2004, 87) Dalam penelitian ini yang menjadi sumber utamanya adalah masyarakat non muslim yang menjadi nasabah di PT. Bank Syariah Mandiri melalui KC. Kota Sibolga melalui wawancara, observasi maupun dokumentasi yang dilakukan oleh peneliti yang berkaitan dengan motivasi masyarakat non muslim menjadi nasabah di PT. Bank Syariah Mandiri KC. Sibolga. Dan Sumber data skunder, data yang diperoleh dari bahan kepustakaan. Pada data skunder, data-data diperoleh dari literan-literan atau bacaan yang relevan dengan penelitian ini.

Untuk mengumpulkan data yang dibutuhkan dalam penelitian ini digunakan instrumen sebagai berikut:

1. Observasi atau pengamatan adalah kegiatan keseharian manusia dengan menggunakan panca indera mata sebagai alat bantu utamanya selain panca indera lainnya seperti telinga, penciuman, mulut dan kulit. Didalam pembahasan ini kata observasi dan pengamatan digunakan secara bergantian. Seseorang yang melakukan pengamatan, tidak selamanya menggunakan panca indera mata saja, tetapi selalu mengaitkan apa yang dilihatnya dengan apa yang dihasilkan oleh panca inderanya. Seperti apa yang dia dengar, apa yang dia cicipi, apa yang ia rasakan dari penciumannya bahkan apa yang ia rasakan dari sentuhan-sentuhan kulitnya.

$$
\text { Observasi sebagai tehnik }
$$
pengumpulan data mempunyai ciri yang spesifik bila dibandingkan dengan dengan tehnik wawancara. Kalau wawancara selalu berkomunikasi dengan orang, maka observasi tidak terbatas pada orang, tetapi juga obyek-obyek alam yang lain.(Sugiono; 2017, 203)

2. Wawancara atau interview adalah teknik pengumpulan data melalui proses tanya jawab lisan yang berlangsung satu arah merupakan pengertian dari Wawancara, artinya pertanyaan datang dari pihak yang mewawancarai secara langsung dan 
bertatapan muka dengan responden. Pewawancaraan adalah orang yang menggunakan metode wawancara sekaligus dia bertindak sebagai pemimpin dalan proses wawancara tersebut.

Materi wawancara adalah persoalan yang ditanyakan kepada responden, berkisar antara masalah atau tujuan penelitian. Pedoman wawancara adalah instrumen yang digunakan untuk memandu jalannya wawancara.(Bungin: 2005, 133) Metode ini pada dasarnya digunakan untuk memperoleh data secara langsung tentang motivasi masyarakat non muslim menjadi nasabah di PT. Bank Syariah Mandiri KC. Sibolga. Bentuk wawancara yang digunakan adalah wawancara penelitian terlebih dahulu membuat pertanyaan-pertanyaan secara struktur ataupun bisa dengan angket yang hasilnya akan peneliti tuangkan dalam hasil penelitian.

3. Dokumentasi adalah pengumpulan dokumen-dokumen yang dibutuhkan dalam penelitian. Dokumentasi dapat berup dokumen yang berisi informasi mengenai lokasi penelitian, surat, foto dan catatan. Hal ini merupakan bukti otentik penelitian telah dilaksanakan dilapangan sehingga data tidak diragukan kebenarannya.

Teknik analisis data dalam penelitian ini adalah purposive sampling. Purposive sampling adalah teknik penentuan sampel berdasarkan pertimbangan-pertimbangan tertentu yang dijadikan sebagai sampel.
POINT Vol. 1, No. 2, Des 2020 Dalam penelitian kualitatif, data diperoleh dari bebagai sumber, dengan menggunakan tehnik pengumpulan data yang bermacammacam dan dilakukan secara trus-menerus sampai datanya jenuh. Penelitin ini dilakukan dalam bentuk analisis kualitatif dengan metode deskriptif. Apabila ditinjau dari proses sifat dan analisis datanya maka dapat digolongkan kepada research deskriptif yang bersifat eksploratif yaitu penelitian deskriptif yng sifatnya menggambarkan lewat analisis dalam penelitian ini bertujuan untuk mendeskripsikan tentang motivasi masyarakat non muslim menjadi nasabah di PT. Bank Syariah Mandiri KC. Sibolga. Setelah data terkumpul, maka dilaksanakan analisis data dengan metode kualitatif deskriptif.(Moleong; 2010, 24)

\section{HASIL DAN PEMBAHASAN}

Motivasi seseorang dapat timbul dari kawan, tetangga maupun dari bank itu sendiri, pada hakikatnya motivasi adalah “menggerakkan" penggerak atau pendorong dalam diri seseorang untuk mau menjadi nasabah di PT. Bank Syariah Mandiri KC. Sibolga.

Hasil penelitian yang dilakukan menerima informasi dari nasabah non muslim di PT. Bank Syariah Mandiri KC. Sibolga. Bahwa masyarakat nasabah non muslim PT. Bank Syariah Mandiri KC. Sibolga memiliki kesan, penilaian dan pendapat nasabah non muslim di PT. Bank 
Syariah Mandiri KC. Sibolga. Sebab apa yang dirasakan ketika menjadi nasabah PT. Bank Syariah Mandiri KC. Sibolga terkhusus yang merupakan nasabah non muslim tentunya akan menjadi indikator adanya nasabah non muslim di PT. Bank Syariah Mandiri KC. Sibolga.

Indikator untuk mengetahui secara rinci motivasi masyarakat non muslim menjadi nasabah di PT. Bank Syairah Mandiri KC. Sibolga adalah melalui produk, pelayanan, promosi, lokasi, biaya administrasi dan bagi hasil. Sehingga peneliti akan dominan mewawancarai masyarakat non muslin menjadi nasabah di PT. Bank Syariah Mandiri KC. Sibolga, sebagai berikut:

1. Produk mempengaruhi masyarakat non muslim menjadi nasabah di PT. Bank Syariah Mandiri KC. Sibolga.

Produk yang ada di setiap Bank berguna bagi nasabah, terutama produk yang ada di PT. Bank Syairah Mandiri KC. Sibolga. Misalnya produk tabungan, dan produk pinjaman. Masyarakat nasabah non muslim PT. Bank Syariah Mandiri KC. Sibolga tentunya ada penilaian yang lebih/positif atau kurang/negative terhadap PT. Bank Syariah Mandiri KC. Sibolga. Berdasarkan hasil penelitian yang telah dilakukan bahwa produk yang ada di PT. Bank Syariah Mandiri KC. Sibolga sudah cukup memuaskan dan bisa bersaing dengan bank-bank lain.

Hasil wawancara dengan Ibu Setama Mirin nasabah non muslim PT. Bank Syariah Mandiri KC. Sibolga mengatakan bahwa bahwa produk yang ada di PT. Bank Syariah Mandiri KC. Sibolga sangat bagus.(Mirin: 23 November 2020) Hasil wawancara dengan Bapak Daniel Petrus nasabah non muslim PT. Bank Syariah Mndiri KC. Sibolga apabila nasabah menabung dan meminjam uang perosesnya cepat dan aman. Karena adanya lembaga penjaminan simpanan sampai dengan 2 Milyard. Jadi apabila terjadi kehilangan uang tidak diragukan lagi karena sudah merupakan tanggung jawab Bank Syariah Mandiri KC. Sibolga.(Simanjuntak: 12 November 2020)

Sementara itu Ibu Netty Situmorang juga nasabah non muslim PT. Bank Syariah Mandiri KC. Sibolga mengatakan bahwa terdapat jasa yang diberikan oleh pihak bank kepada nasabah seperti Mobile Banking, kegunaannya sangat banyak diantaranya bisa langsung cek saldo dari HP tanpa perlu ke ATM lagi dari Mobile Banking ini juga kita bisa melakukan pembayaran, misalnya air dan listrik. Berbeda halnya dengan Ibu Neni Simarmata beliau mengatakan kurang tau apa saja produk-peoduk yang ada di PT. Bank Syariah Mandiri KC. Sibolga.

Motivasi dilihat sebagai peroses terhadap suatu tujuan yang ingin dicapai, terutama tujuan pribadi. Semakin tinggi hadiah yang kita berikan, maka semakin besar kemungkinan kita melakukan kegiatan yang akan menghasilkan keuntungan. 
2. Pelayanan mempengaruhi masyarakat non muslim menjadi nasabah di PT. Bank Syariah Mandiri KC. Sibolga.

Pelayanan sangat penting dan merupakan unjung tombak perusahaan yang akan langsung berhadapan dengan nasabah. Para petugas pelayanan bukan hanya bertindak sebagai mediator/komunikator, namun harus bisa membantu dan memahami bahwa nasabah merupakan aset yang paling penting yang harus dijaga dan dipelihara di dalam perusahaan itu sendiri agar bisa dipertahankan keberadaanya.

Berdasarkan hasil wawancara yang telah dilakukan dengan Bapak Hansen bahwa pelayanan yang ada di PT. Bank Syariah Mandiri KC. Sibolga ini sangat memuaskan dan bagus dibandingakan dengan bank yang lain. Sama halnya dengan Ibu Lidiana Aritonang dan Nara Nainggolan pelayanan yang dilakukan oleh PT. Bank Syariah Mandiri KC. Sibolga sangat bagus dan ramah-ramah. Bukan itu saja beliau juga mengatakan di ruang tunggu PT. Bank Syariah Mandiri KC. Sibolga menyediakan minuman jika nasabah haus tidak perlu lagi keluar dari Bank Syriah Mandiri KC. Sibolga.(Hansen: 12 November 2020.)

Hasil wawancara dengan Bapak Saf Esthomihi Sinaga, Natalia Sihombing, Benton Parulian Manik yang menjadi nasabah non muslim juga mengatakan bahwa pelayanan yang dilakukan PT. Bank Syariah Mandiri KC. Sibolga sangat memuaskan dan
POINT Vol. 1, No. 2, Des 2020 pelayanannya ramah-ramah, dan apabila nasabah bertanya kepada karyawan bank langsung ditanggapi dan diberi respon yang baik.

3. Promosi mempengaruhi masyarakat non muslim menjadi nasabah di PT. Bank Syariah Mandiri KC. Sibolga.

Sebagaimana hasil wawancara dengan Bapak Paulus Sitorus nasabah non musllim di PT. Bank Syariah Mandiri KC. Sibolga mengatakan promosi yang ada di PT. Bank Syariah Mandiri KC. Sibolga sangat giat marketing-marketingnya untuk melakukan promosi di pasar. Bapak Paulus Sitorus juga mengatakan pernah melihat karyawan bank syariah mandiri KC. Sibolga bersosialisai di Sekolah.(Sitorus: 12 November 2020)

Berdasarkan hasil wawancara yang dilakukan oleh peneliti tentang promosi PT. Bank Syariah Mandiri KC. Sibolga Ibu Dessy Trilia Natalia dan Bapak Daniel Petrus Simanjuntak mengatakan promosi yang ada di PT. Bank Syariah Mandiri KC. Sibolga cukup baik, karena ketika hendak menabung di PT. Bank Syariah Mandiri KC. Sibolga pegawainya aktif menawarkan berbagai produk dan hadiah yang diberikan oleh PT. Bank Syariah Mandiri KC. Sibolga.(Natalia: 23 N)

Sementra itu hasil wawancara yang dilakukan dengan lbu Ronny Lintang mengatakan hal yang sama tentang promosi yang ada di PT. Bank Syariah Mandiri KC. Sibolga menurut beliau sangat aktif 
menawarkan produk dan hadiah-hadiahnya sangat bagus dan menarik.

Berbeda halnya dengan Ibu Irma Sinaga dan Lenni Tania, beliau mengatakan Promosi yang dilakukan oleh PT. Bank Syariah Mandiri KC. Sibolga tidak pernah beliau lihat sebelunya.

4. Lokasi mempengaruhi masyarakat non muslim menjadi nasabah di PT. Bank Syariah Mandiri KC. Sibolga.

Berdasarkan hasil wawancara yang dilakukan oleh peneliti tentang lokasi di PT. Bank Syariah Mandiri KC. Sibolga dengan Ibu Evita Sari Limbong mengatakan lokasi PT. Bank Syariah Mandiri KC. Sibolga sangat strategis karena pas di Kota Sibolga.(Limbong: 12 November 2020)

Sementara hasil wawancara dengan Ibu Roselli Purba mengatakan hal yang sama sangat strategis. Beliau juga mengatakan lokasi PT. Bank Syariah Mandiri KC. Sibolga tidak harus naik Becak naik angkot juga bisa langsung ke lokasi PT. Bank Syariah Mandiri KC. Sibolga.(Purba; 12 November 2020.)

Sedangkan hasil wawancara dengan Bapak Muller Sibuea dengan Ibu Tania Sihombing mengatakan bahwa lokasi PT. Bank Syariah Mandiri KC. Sibolga sangat terjangkau dan dekat dengan rumah beliau.

Berbeda halnya degan Bapak Muara Alatas Marbun, Bapak Martinus Halawa, Ibu Agustina Sidabutar dan Bapak Dedi Pasaribu nasabah non muslim di PT. Bank Syariah Mandiri KC. Sibolga, beliau mengatakan lokasi PT. Bank Syariah Mandiri KC. Sibolga sangat jauh dari rumah beliau.

5. Biaya Administrasi mempengaruhi masyarakat non muslim menjadi nasabah di PT. Bank Syariah Mandiri KC. Sibolga.

Sedangkan hasil wawancara yang dilakukan oleh peneliti dengan Bapak Paulus Amin dan Bapak Sorimuda tentang administrasi, beliau mengatakan jika nasabah menabung dan melakukan peminjaman, biaya administrasi yang dikeluarkan oleh nasabah relatif murah sehingga para nasabah merasa tertarik untuk bertrransaksi di PT. Bank Syariah Mandiri KC. Sibolga.(Sitorus; 23 November 2020.)

Sama halnya dengan yang dikataka Ibu Adena Hutagalung dan Bapak Roland Pasaribu nasabah non muslim PT. Bank Syariah Mandiri KC. Sibolga beliau mengatakan biaya administrasi yang dikeluarkan oleh nasabah relatif murah.

6. Bagi Hasil mempengaruhi masyarakat non muslim menjadi nasabah di PT. Bank Syariah Mandiri KC. Sibolga.

Berdasarkan hasil wawancara yang dilakukan oleh peneliti dengan Bapak Johan Junaedi tentang bagi hasil di PT. Bank Syariah Mandiri KC. Sibolga. Beliau mengatakan bahwa bagi hasil yang ada di PT. Bank Syariah Mandiri KC. Sibolga sedikit dan tidak membebankan dan memberatkan nasabah. 
Sama halnya dengan Bapak Damaris Ginting nasabah non muslim di PT. Bank Syriah Mandiri KC. Sibolga menurut beliau bagi hasil yang ada di PT. Bank Syariah Mandiri KC. Sibolga bagi hasilnya tidak terlalu besar.(Ginting; 12 november 2020)

Pembahasan Penelitian

Berdasarkan hasil penelitian yang dilakukan, peneliti melihat pada umumnya banyak masyarakat non muslim termotivasi dengan pelayanan yang dilakukan oleh PT. Bank Syariah Mandiri KC. Sibolga karena pelayanan yang dilakukan oleh pihak bank sangat memuaskan. motivasi masyarakat non muslim menjadi nasabah di PT. Bank Syariah Mandiri KC. Sibolga lokasinya sangat terjangkau dan pas di tepi jalan raya, promosi yang dilakukan oleh PT. Bank Syariah Mandiri KC. Sibolga sangat giat dengan cara bersosialisasi di pasar maupun di Sekolah.

Disamping itu ada juga faktor lain yang menjadi motivasi masyarakat non muslim menjadi nasabah di PT. Bank Syariah Mandiri KC. Sibolga karena Kantor KEMENAG yang merekomedasikan supaya menjadi nasabah di PT. Bank Syariah Mandiri KC. Sibolga karena Pegawai yang berada di Kota Sibolga menerima gaji di PT. Bank Syariah Mandiri KC. Sibolga. Dari semua motivasi masyarakat non muslim yang menjadi nasabah di PT. Bak Syariah Mandiri KC. Sibolga yang paling dominan adalah dari segi pelayanan.

\section{PENUTUP}

\section{Kesimpulan}

Berdasarkan hasil penelitian dan pembahasan pengaruh pengetahuan terhadap minat memilih produk PT. Bank Syariah Mandiri Padangsidimpuan (studi kasus pada guru al-azhar bi'ibadillah ujung gading kecamatan batang angkola) dengan melalui penyebaran angket/kuesioner kepada guru Al-Azhar Bi'ibadillah, maka dapat diambil kesimpulan bahwa pengetahuan berpengaruh dan signifikan terhadap minat memilih produk PT Bank Syariah Mandiri Padangsidimpuan.

Hipotesis yang menyatakan pengetahuan berpengaruh terhadap minat memilih produk PT Bank Syariah Mandiri Padangsidimpuan dapat diterima. Presentase sumbangan pengetahuan terhadap minat memilih produk PT Bank Syariah Mandiri Padangsidimpuan sebesar $12 \%$ dan selebihnya $88 \%$ dipengaruhi oleh variabel independen lain yang tidak dibahas dalam penelitian ini.

\section{Saran}

Semoga adanya peningkatan jumlah nasabah ke depannya.

\section{DAFTAR PUSTAKA}

Akbar, M. H. (2019). Analisis Faktor-Faktor Yang Mempengaruhi Minat Nasabah Non Muslim Dalam Menggunakan Jasa Bank Syariah Di Makassar. Universitas Islam Negeri Alauiddin Makassar.

Arikunto, S. (2006). Prosedur Penelitian Suatu Pendekatan Praktik. Rineka Cipta.

Berliana, C. (n.d.). wawancara.

Bungin, B. (2005). Metodologi Penelitian Kuantitatif Komunikasi, Ekonomi, dan 
Kebijakan Publik Serta IImu-IImu Sosial Lainnya. kencana prenada media group.

Diana. (2016). Faktor-Faktor Yang Mempengaruhi Minat Nasabah Masyarakat Non Muslim di PT. Bank Tabungan Negara (Persero) tbk Kantor Cabang Syariah Medan. Fakultas Agama Islam Universitas Muhammadiyah Sumatera Utara Medan.

Isa, M. (2019). Pengaruh Kualitas Pelayanan Terhadap Kepuasan Penumpang Menggunakan Jasa Angkutan Penyeberangan PT. ASDP Indonesia Ferry (Persero) Cabang Sibolga. Jurnal Ekonomi \&Ekonomi Syariah, 2 no 2.

Karim, A. A. (2016). Bank Islam Analisis Fiqih dan Keuangan. Raja Grafindo Parsada.

Machmud, A. (2010). Bank Syariah, Teori, Kebijakan, dan Studi Empiris di Indonesia.
Mardalis. (2007). Penelitian suatu pendekatan proposal.

Moleong, L. J. (2010). Metode Penelitian Kualitatif.

Nofinawati. (2017). Pengaruh Pelatihan dan motivasi terhadap Kinerja Pegawai pada Puskesmas Hutaraja Kecamatan Muara Batang Toru. 5 no 1.

Subagyo, P. J. (2004). Metode Penelitian Dalam Teori dan Praktek.

Sudarwan Danin. (2012). Motivasi Kepemimpinan.

Sugiono. (2012). metode penelitian bisnis. Alfabeta.

Syarofah, A. (2016). Pengaruh Kualitas Produk Tabungan Bank Syariah Mandiri Terhadap Kepuasan Nasabah Non Muslim. Insitut Agama Islam Negeri Purwokerto. 